\title{
Chaotropic Etching for Fabricating Microwells for Cell Culture
}

\author{
Nobuhiro Tamai Non-member (Tokyo University) \\ Hiroyuki Moriguchi Non-member (Tokyo University) \\ Yuzo Takayama Non-member (Tokyo University) \\ Yasuhiko Jimbo Member (Tokyo University) \\ Ikuro Suzuki Non-member (Tokyo University) \\ Kenji Yasuda Non-member (Tokyo Medical \& Dental University)
}

Keywords : cell culture, micro-fabrication, chaotropic effect, directional growth

Formation of simple neuronal networks in vitro is one of the promising methods to study biological information processing. Agarose microchambers have several advantages to form and maintain simple network structures. Here, in this work, a novel method for fabricating microwells in an agarose-layer is reported. Chaotropic effects of sodium iodide ( $\mathrm{NaI}$ ) is applied for etching agarose films. Fig. 1 shows schematic drawing of apparatus for chaotropic etching. The system consists of a micropipette fixed to micromanipulator and a cultivation dish containing agarose-gel layer on a substrate for cell culture.

As shown in Fig. 2, the process of fabricating microwells on the surface of an agarose layer is (a) alignment of a micropipette filled with $\mathrm{NaI}$ solution to the object location by moving microscope stage, (b) contact of the micropipette and ejection of $\mathrm{NaI}$ solution and (c) washing out dissolved agarose-gel by filling cultivation dish with sterilized water.

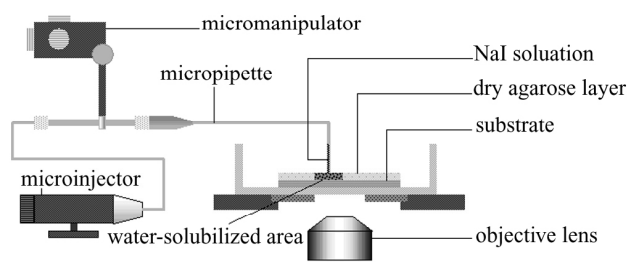

Fig. 1. Schematic illustration of a chaotropic etching system

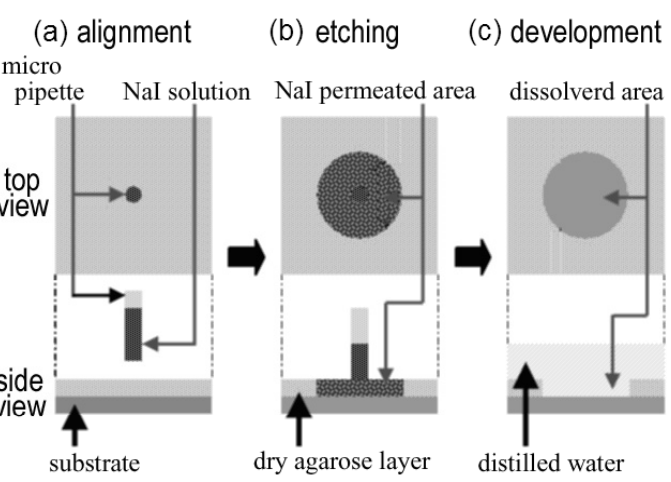

Fig. 2. The procedures for fabricating a microwell
Fig. 3 shows a microwell formed by chaotropic etching method. Fig. 3A shows $\mathrm{NaI}$ permeated area spreading in a circle before washing out and Fig. 3B shows a microwell washed by distilled water injection. The size of the well was determined by the quantity of ejected $\mathrm{NaI}$ solution and its diffusion time. Conditions for fabricating wells of 100 to $600 \mathrm{um}$ diameter were established.

Rat hippocampal neurons were successfully cultured in the wells. Fig. 4A shows a single neuron cultivated for 21 days in a microwell. Fig. 4B shows a cluster of hippocampal neurons in a microwell on a MEA substrate. These results indicate that chaotropic etching can be used for the pattern formtion of cultured neurons even on MEA substrates. Combining this method with MEA substrates will enable us of recording neuronal activity from simple neuronal networks as well as co-culture systems of heterogeneous tissues.
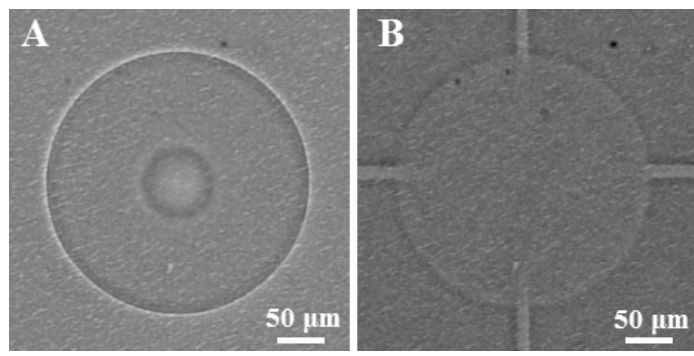

Fig. 3. Microwells formed by the chaotropic etching process. (A) NaI permeated area before development. (B) Developed pattern with four photo-thermally etched conduits
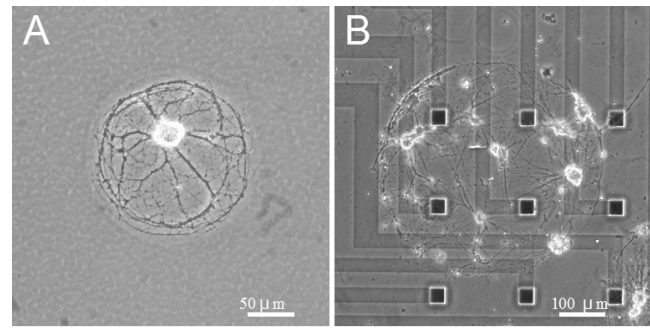

Fig. 4. Cultured rat hippocampal neurons. (A) A single neuron cultured in a microwell fabricated by chaotropic etching (21 DIV). (B) Rat hippocampal neurons on a MEA substrate (6 DIV) 


\section{カオトロピックエッチング法による 細胞培養用マイクロウェルの作成}

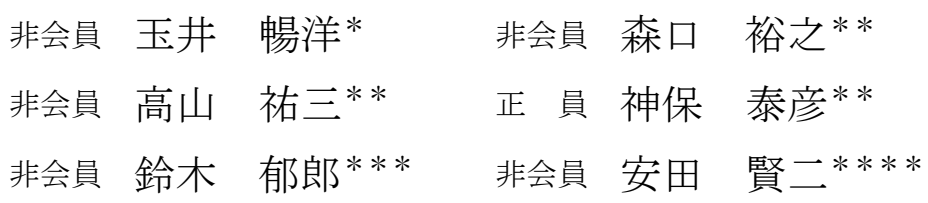

\section{Chaotropic Etching for Fabricating Microwells for Cell Culture}

Nobuhiro Tamai*, Non-member, Hiroyuki Moriguchi**, Non-member, Yuzo Takayama**, Non-member, Yasuhiko Jimbo**, Member, Ikuro Suzuki***, Non-member, Kenji Yasuda****, Non-member

Formation of simple neuronal networks in vitro is one of the promising methods to study biological information processing. Agarose microchambers have several advantages to form and maintain simple network structures. Here, in this work, a novel method for fabricating microwells in an agarose-layer is reported. Chaotropic effects of sodium iodide ( $\mathrm{NaI}$ ) is applied for etching agarose films. A conventional glass micropipette filled with $\mathrm{NaI}$ solution was aligned and a small amount of $\mathrm{NaI}$ was ejected to surface of the film. The agarose was denatured by the soaked NaI. The denatured agarose was washed out by distilled water. The size of the well was determined by the quantity of ejected $\mathrm{NaI}$ solution and its diffusion time. Conditions for fabricating wells of 100 to $600 \mu \mathrm{m}$ diameters were established. Multiple wells up to 100 were formed on a single surface sequentially by programmed movement of the microscope stage. Rat hippocampal neurons were successfully cultured in the wells. Combining this method with microelectrode-array substrates will enable us of recording neuronal activity from simple neuronal networks as well as co-culture systems of heterogeneous tissues.

キーワード : 神経細胞, 細胞培養, 微細加工, カオトロピック効果, 成長方向制御

Keywords : neuron, cell culture, micro-fabrication, chaotropic effect, directional growth

\section{1. はじめに}

パターン認識をはじめとする様々な分野において，近年 ニューラルネットワーク理論に基づく情報処理方式が導入 されつつあり，実用化の段階にまで達してきているが，実 際の生物のニューロンとそのネットワークの動作について

* 東京大学大学院工学系研究科

于113-8656 東京都文京区本郷 7-3-1

Graduate School of Engineering, University of Tokyo, 7-3-1, Hongou, Bunkyo-ku, Tokyo, 113-8656

** 東京大学大学院新領域創成科学研究科

干277-8563 千葉県柏市柏の葉 5-1-5 Graduate School of Frontier Sciences, University of Tokyo,

5-1-5, Kashiwanoha, Kashiwa-shi, Chiba, 277-8563

*** 東京大学大学院総合文化研究科

干153-8902 東京都目黒区駒場 3-8-1

Graduate School of Arts and Sciences, University of Tokyo, 3-8-1, Komaba, Meguro-ku, Tokyo, 153-8902

****東京医科歯科大学生体材料工学研究所

干101-0062 東京都千代田区神田駿河台 2-3-10 Institute of Biomaterials and Bioengineering, Tokyo Medical and Dental University,

2-3-10, Kanda-Surugadai, Chiyoda-ku, Tokyo, 101-0062
は解明されていない事項が少なくない。単一ニューロンレ ベルで行われる信号処理, 多数のニューロンの集合体にお ける情報の分散表現と並列処理, そしてハードウェア自体 が周囲の状況に応じて変化していく可塑性が生体情報処理 機能を構成する主要な要素であり, 各段階のメカニズム解 明だけでなく, それらを統合した理解が求められる。電気 生理学分野における実験技術の進歩により単一ニューロン の能動的な特性が観測されるようになり ${ }^{(1)}$, 分子生物学の発 展を背景に, シナプス可塑性に関与する分子に関する知見 も蓄積されつつある(2)。しかしながら, 神経回路活動として 表現される機能と個々のニューロンの振る舞い, その可塑 的な変化との関係はほとんど解明されていないのが現状で ある。

個々のニューロンを可視化し, かつ集団としての振る舞 いを観測対象とし得る実験手法として細胞パターニング技 術の研究が進められてきた。脳神経系の様々な部位から採 取した細胞を 2 次元的に展開し, 人工環境下で維持する多 様な技術が確立 ${ }^{(3)}$ されていることを前提として, ニューロン 
の基板表面への接着位置や相互に結合して神経回路を構成 する神経突起の成長方向を人為的に制御することで回路構 造を把握・制御可能なシンプルな神経回路を構築すること を目指している。細胞接着性の分子のパターニング(4), 基板 表面の立体構造 ${ }^{(5)}$ な゙，様々な制御手法が提案され，一定の 成果が得られた ${ }^{(6)}$ 。この成長方向制御技術を多点電極基板 (Micro-Electrode Array: MEA) (7)(8) と組み合わせることによ り，神経回路を構成する多数のニューロンについて，その 電気活動を同時記録することが期待されたが，実際に信号 計測結果が報告された例 ${ }^{(9)}$ は多くない。その原因は, 電気活 動やシナプス伝達が十分に活性化されるまでに要する期 間，ネットワーク構造を維持することが困難であったこと にある。

培養系で個々のニューロンの位置と相互の結合構造を長 期間制御する技術としてアガロースマイクロチャンバ 法 ${ }^{(10)(11)}$ が提案され, 回路構造の変化と電気活動の対応が観 測されるようになった ${ }^{(12)}$ 。この手法は，基板上に細胞がほ とんど接着しない性質を有するアガロースゲルを膜状に展 開し，赤外レーザ光照射によって局所的に加熱・溶解する ことで，細胞接着面を作成するものである。細胞体を格納 するマイクロチャンバとチャンバ同士をつなぎ神経突起を 伸張させる通路であるマイクロチャネルから構成されるマ イクロパターン内で細胞培養を行うことにより, 単一細胞 レベルで制御された神経回路を構築することができる。こ れまで難しかったネットワーク構造を長期間維持すること ができるという点に加え, アガロースゲルが従来使用され ていたフォトレジストなどと比較し低温で容易に加工でき るため, 培養開始後に神経回路の成長段階に応じて回路構 造を変化させることができるというメリットがある。

今回, アガロースマイクロパターンを，化学的なエッチ ングで作成する簡便な手法を開発した。レーザ加工では光 路中に存在する材料の光吸収特性に応じた出力制御が必要 となるのに対し, 化学エッチングは顕微鏡下でのマニピュ レータとステージの移動という, 通常の電気生理実験シス テムがそのまま適用可能な簡易手法である点が特徵であ る。本論文では, カオトロピックエッチングと呼ぶ提案手 法で必要な加工精度を得る条件, 加工された表面での細胞
培養について検討した結果を報告する。

\section{2. 実験方法}

〈2·1〉 アガロース薄膜の作成＼cjkstart基板としてポリスチ レン製細胞培養典. (Corning), カバーグラス (Matsunami NEO MICRO COVER GLASS $25 \times 60 \mathrm{~mm}$ ), MEA の 3 種類を使用 した。MEA はパイレクスガラス基板上に ITO (Indium-TinOxide：透明導電性材料）で電極パターンを形成し, 電極先 端部を除いてシリコン系のフォトレジスト ${ }^{(13)}$ で被覆, さら に電極先端部を白金黒でコーティングしたものを用いた。 詳細な製作プロセスは，既報 ${ }^{(14)} に$ 記述したものと同様であ る。今回使用したものは, サイズ $30 \times 30 \mu \mathrm{m}$ の電極 64 個が 中心間距離 $180 \mu \mathrm{m}$ で $8 \times 8$ のマトリクス状に配置されたも のである。この 3 種類の基板表面に加熱した低融点アガロ 一ス (Agarose L, Wako) の $2 \%$ 水溶液 $100 \mu \ell$ を滴下し, 4,000 $\mathrm{rpm}, 10$ 秒間の条件でスピンコートした後, 1 時間乾燥させ た。以上の条件で形成されたアガロース薄膜は，4, $5 \mu \mathrm{m}$ 程 の厚さになり, さらに乾燥させることで数〜 10 分の 1 にな る。

〈2·2〉 カオトロピックエッチング＼cjkstart得られたアガロ 一ス薄膜をエッチングする試薬として NaI 水溶液を使用し た。ヨウ素イオンの持つカオトロピック効果 ${ }^{(15)}$ によってア ガロース薄膜中に残る水分子間の相互作用が不安定にな り, 結果として疎水結合が弱められたアガロースが常温で 水に可溶化するという現象を利用するものである。ここで は NaI（Wako）の $7 \mathrm{M}$ 水溶液を調整し, ガラスピペットに 充填した。ガラスピペットは, 直径 $1 \mathrm{~mm}$ のガラス管 (GD-1, Narishige）を材料として, 通常の細胞膜電位計測用ガラス管 電極と同様の手順を用い, 先端径 $20 \mu \mathrm{m}$ を基準として加工, 製作した。

図 1 にエッチングシステムの基本構成を示す。試料の位 置を制御し, エッチングの進行状況を観察する電動ステー ジ付倒立顕微鏡 (IX71, Olympus), マイクロピペットの位 置決めを行うマイクロマニピュレータ (Narishige), それに NaI 溶液の放出を制御するマイクロインジェクタ (Cell Tram Air, Eppendorf) が主要構成要素である。このシステムを用 いて図 2 に示す手順でエッチング処理を行った。

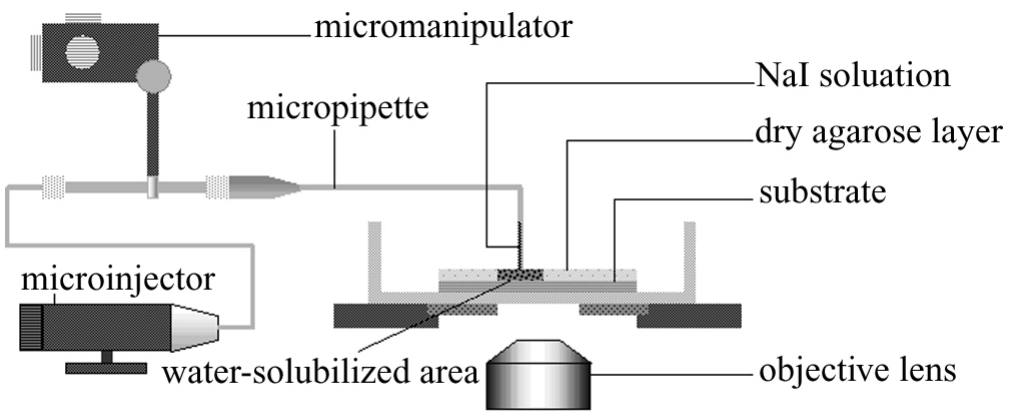

Fig. 1. Schematic illustration of a chaotropic etching system. The system is composed of a micromanipulator, a microinjector, and a glass micro-pipette filled with $\mathrm{NaI}$ solution. 
表面にアガロース薄膜を形成した試料を顕微鏡ステージ 上中央にセットし, NaI 溶液を充填したマイクロピペットを 所定の位置に移動させる (Alignment)。ついでマニピュレー タの上下方向の操作により, ピペット先端を試料表面に接 触させる。ピペットから放出された NaI 溶液はアガロース 層を拡散し，カオトロピック効果によりアガロース薄膜を 変性させる（Etching）。試料表面からピペットを離した後, 滅菌処理を施した蒸留水で洗浄することで変性した領域の アガロースを溶解除去する (Development)。

〈2·3〉加工精度の評価 エッチングされる範囲を決 める主要な要因は, ピペットから放出される NaI 溶液量と アガロース層内でのその拡散距離であると考えられる。こ こでは放出量を制御するパラメータとして，ピペット先端 径 $\phi$, インジェクタによりピペット内溶液に印加する圧力 $p$, ピペット先端と試料表面との接触時間 $t$ をとり, 得ら れるマイクロウェルの直径を指標として評価を行った。拡 散距離については，ピペット先端を試料表面から離してか ら蒸留水による洗浄を実行するまでの時間 $t$ 皇パラメータ とし，同様にマイクロウェルの直径を測定した。

〈2·4〉 細胞培養 細胞培養を行う基板については, アガロース薄膜形成前に細胞接着性の因子（Poly-D-Lysine (Sigma)）による基板表面のコーティングを行った。ついで アガロース層のコーティング，マイクロパターンの形成を 行ったものを用いた。細胞はエーテル深麻酔下の妊娠 18 日 齢 Wistar Ratから取り出した胎児から海馬を採取し, 文献の 手法 ${ }^{(16)}$ に従い細胞懸濁液を調整した。調整した細胞懸濁液 を基板上に播き， $37{ }^{\circ} \mathrm{C}, \mathrm{CO}_{2} 5 \%$, 水蒸気飽和の条件で培 養を行った。培養液には, Neurobasal Medium (Gibco) に $2 \%$ B27 supplement (Gibco), $0.5 \mathrm{mM}$ L-glutamine (Gibco), 100 unit/ml Penicillin (Gibco), $0.1 \mathrm{mg} / \mathrm{ml}$ Streptomycin (Gibco) を加 えたものを使用し， 1 週間に 1 回半量交換した。

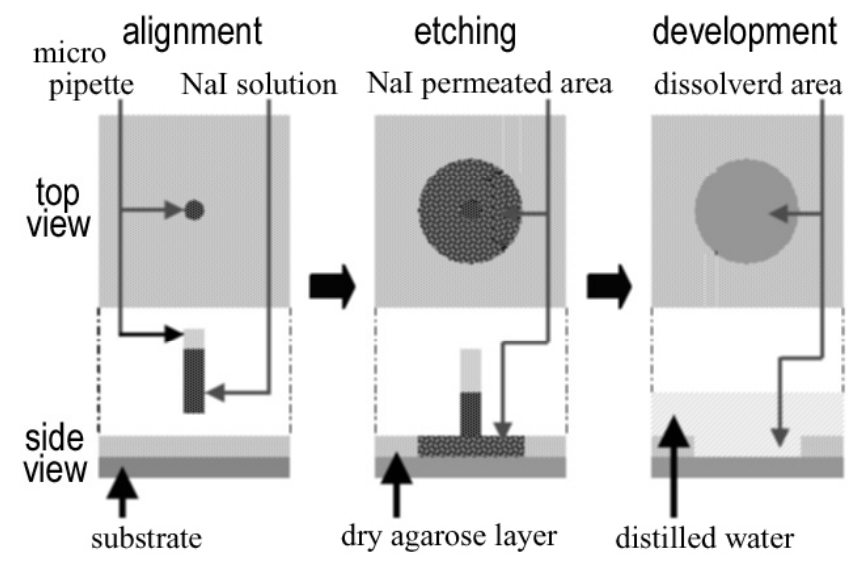

Fig. 2. Procedures for chaotropic etching. First, a micropipette filled with $\mathrm{NaI}$ solution is aligned to the object location. NaI solution starts to diffuse into the dry agarose layer. The NaI permeated area is water-soluble at room temperature. Microwell patterns are developed by distilled water.

\section{3. 実験結果}

〈3·1〉 カオトロピックエッチングによるマイクロウェ ル 図 3 に, カオトロピックエッチングにより形成した マイクロウェルの例を示す。(A)はポリスチレン製細胞培養 皿底面に形成した乾燥アガロース薄膜表面にマイクロピペ ットを接触させて NaI 水溶液を注入した直後の写真である。 ピペットの接触部分を中心にしてカオトロピック効果によ り変性したアガロース層が円状に広がっている様子がわか る。円の中心部付近に円状に見える部分が存在するが，こ れは乾燥アガロースゲルが水分を吸収することによって再 膨潤し盛り上がるためである。蒸留水による洗浄を行い, さらにアガロース薄膜の加工法として確立されている photo-thermal 法(10)(11)を適用して縦横それぞれ 1 本ずつのラ イン加工を加えた結果を(B)に示す。形成された円内に photo-thermal 法(10)(11)で行ったライン加工による表面状態の 変化がほとんど認められないことから, カオトロピックエ ッチングの手法で, アガロース層は基板表面に達するまで 全て溶解除去されていることが確認された。

図 3(C)は, マイクロピペットを顕微鏡視野の中央に固定, 上下方向の移動操作のみとし, ガラス基板上にアガロース 層を堆積した試料をセットした電動ステージをプログラム 制御で移動させ，マトリクス状に分布するマイクロウェル の連続作成を行った結果である。中心間距離 $300 \mu \mathrm{m}$ の設定 で $10 \times 10$ のウェルを製作した。このような多段階の連続操 作においても, 設計どおりのマルチウェル構造が再現性よ く形成されることを確かめた。さらに，MEA 基板について もウェルの作成を試み，(D)に示すとおり，基板表面材料の 多様性に影響を受けることなくマイクロウェルを得ること ができた。

〈3·2〉加工精度の評価最初に, スピンコート後の アガロース薄膜乾燥時間の影響を調べた。図 4 にその結果

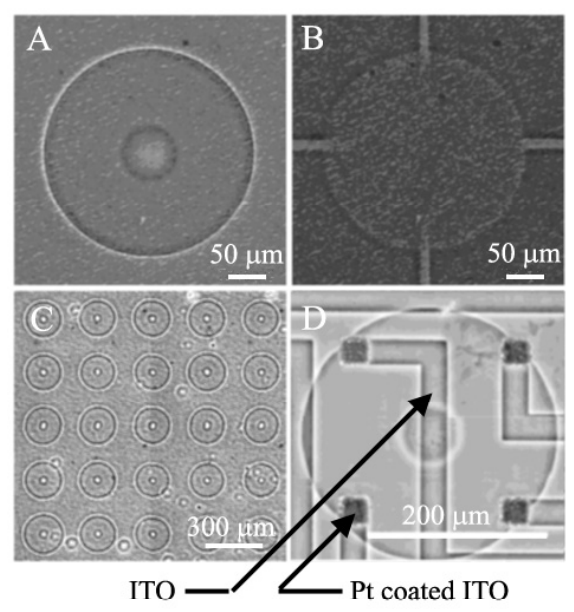

Fig. 3. Microwells formed by the chaotropic etching process. (A) NaI permeated area before development. (B) Developed pattern with four photo-thermally etched conduits. (C) Multi-well patterns. (D) Patterns on a MEA substrate. 
を示す。アガロース薄膜形成後 NaI によるエッチング操作 を実行するまでの時間をパラメータとし，その他の条件を 一定にした場合のマイクロウェルの直径である。最初の 30 分間でウェルの直径は約 $25 \%$ の減少を示し, その後は 3 時 間以上経過してもほとんど変化しないことがわかる。力才 トロピック効果がアガロース薄膜中の水の状態変化を利用 するものであるため, 効果が及ぶ領域が残留する水分量に 依存したものと考えられ，この影響を排除するためには少 なくとも 30 分間の乾燥時間を要することがわかる。以上の 結果に基づき, ピペット先端径 $\phi$, ピペット内液圧力 $p$, エッチング液放出時間 $t_{1}$, 拡散時間 $t_{2}$ をパラメータとする 評価においては薄膜形成後 1 時間の乾燥処理を施した試料 を用いた。

図 5 は種々の作成条件に対するマイクロウェルサイズの 変化である。 $\phi=20 \mu \mathrm{m}, p=0, t_{1}=1 \mathrm{~s}, t_{2}=60 \mathrm{~s}$ を基準 とし，特定のパラメータを変化させた場合について評価を

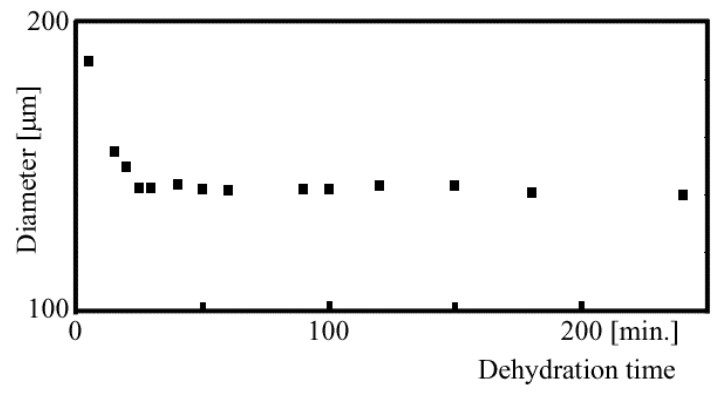

Fig. 4. Diameter of microwells fabricated by chaotripic etching. Dependence on dehydration time after agarose-layer deposition.

(A)

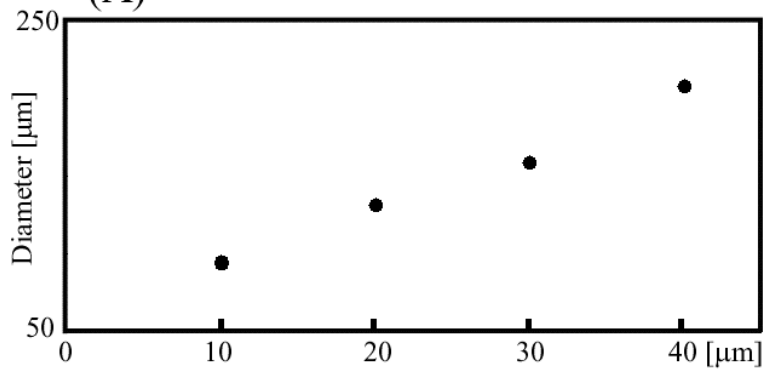

(C)

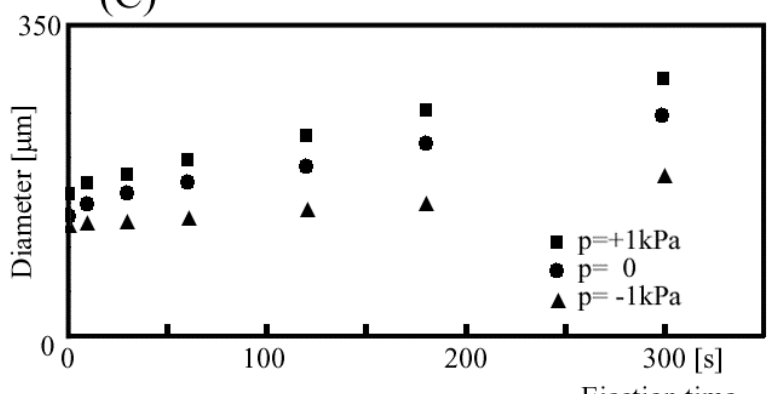

行っている。ピペットサイズについては先端径 10, 20, 30, 40 $\mu \mathrm{m}$ の 4 つ場合につき計測を行ったが，この範囲では線形 に近い関係が得られている。ピペット内液に印加する圧力 については毛細管現象の寄与が大きく, 圧力をかけない状 態でも直径約 $130 \mu \mathrm{m}$ の領域がエッチングされ， $3 \mathrm{kPa}$ の陰 圧印加の条件下でも溶液の放出が生じるという結果になっ た。溶液放出時間についても最初の接触時における毛細管 現象の影響が大きく, その後の変化はゆるやかである。傾 きは印加する圧力に対する依存性が認められ，一定の陰圧 を印加することにより加工サイズの接触時間に対する依存 性を小さく抑えることが可能である。拡散時間については 2 分間でほぼ飽和するという結果になった。基準条件で複数 のマイクロウェルを作成し, 加工サイズの再現性を評価し た結果, 平均サイズ $130 \mu \mathrm{m}$, 標準偏差 $1.5 \mu \mathrm{m}(N=4)$ となり, 約 $1 \%$ の誤差で加工精度が確保できることを確かめた。

$\langle 3 \cdot 3\rangle$ 細胞培養カオトロピックエッチングの手法 により作成したマイクロウェル内でラット海馬細胞の培養 を行った結果を図 6 に示す。(A)はウェルの直径を約 $100 \mu \mathrm{m}$ とし, $20 \mathrm{cell} / \mathrm{mm}^{2}$ の濃度で播種し, ウェル内で単一細胞が 培養されている例である。ウェルの中心付近に接着した細 胞体から伸びる数本の神経突起がウェルの外周部に到達 後，物理的障壁にそって円弧状に伸長していることがわか る。(B)は MEA 基板上のアガロース膜に直径約 $350 \mu \mathrm{m}$ のウ エルを作成し, $570 \mathrm{cell} / \mathrm{mm}^{2}$ で播種し培養を行った例である。 培養開始後 6 日の時点でウェル内に細胞が接着し, ネット ワークを作っている様子がわかる。ウェルの外部への細胞 移動, 突起の伸長はほとんど認められない。ほとんどの突 起がウェル内にとどまっており, カオトロピックエッチン グの手法で作成した基板表面が十分な細胞接着性を有して

(B)

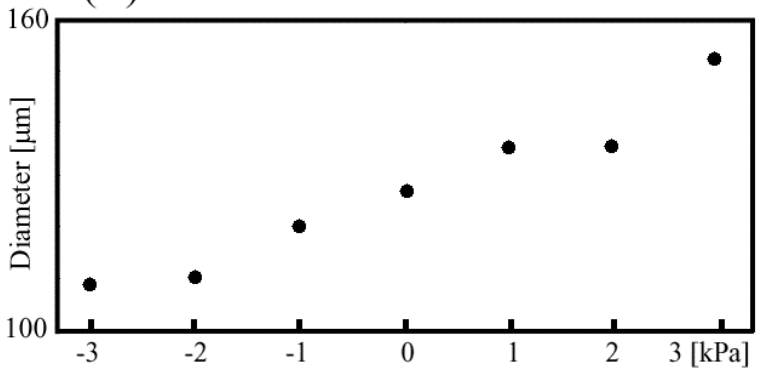

(D) Ejection pressure

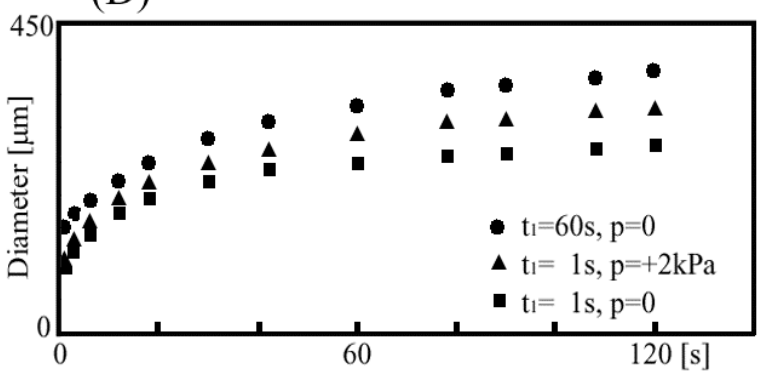

Diffusion time

Fig. 5. Size-determinant parameters for chaotropic etching. Diameters of developed microwells are measured for various fabrication conditions. Dependence on the tip size of micropipette (A), applied ejection pressure (B), ejection time (C), and diffusion time (D). 

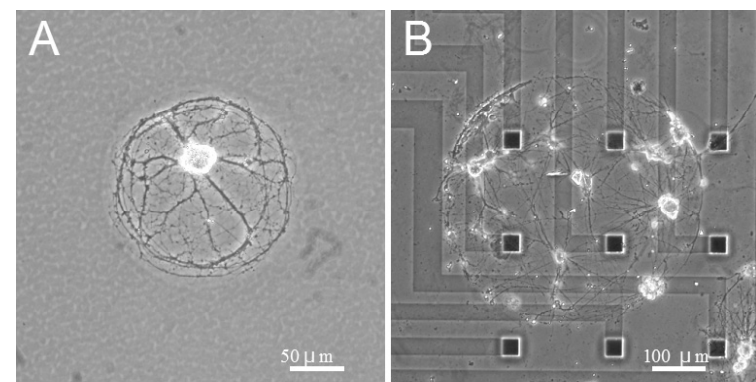

Fig. 6. Cultured rat hippocampal neurons. (A) A single neuron cultured in a microwell fabricated by chaotropic etching (21 DIV). (B) Rat hippocampal neurons on a MEA substrate (6 DIV).

おり，かつ細胞培養が可能であることが示された。また NaI 溶液を使用しない通常の培養と比較した結果, 加工プロセ スで使用した試薬類が培養環境に明確な影響を与えること がないことを確認した。

\section{4. 考察}

〈4·1〉 マイクロウェルのサイズ制御＼cjkstart個々の細胞を 可視化し，かつその結合関係を人為的に制御したシンプル 神経回路からの信号計測という視点から考えると, MEA 基 板の各電極部分に 1 つずつ細胞を配置することが望ましい。 図 6(B)に見られるとおり, ラット海馬の神経細胞の細胞体 は, 大きいもので $30 \mu \mathrm{m}$ 程度であり，これを収容すること を考えると, 直径 $100 \mu \mathrm{m}$ 以下のマイクロウェルを再現性良 く形成できる技術が求められる。

作成するウェルを微細化する際の最も直接的な要素はピ ペット先端径であり，これを $10 \mu \mathrm{m}$ とした場合について， 直径 $100 \mu \mathrm{m}$ 末満のウェルが得られることが確かめられてい る（図 5(A)）。先端径のさらに小さなピペットを製作するこ とは容易であるが，溶液の放出が毛細管現象の影響を強く 受けることを考慮すると, 放出量の制御は必ずしも単純な プロセスにはならない。時間的な要素を今回検討した条件 に固定し, 図 5(A)のデータを外挿して得られるウェルの直 径 $50 \mu \mathrm{m}$ 付近を目標にピペットサイズ縮小の効果を把握す る必要がある。図 5(B)のデータは，ピペット内圧の制御に より毛細管現象による溶液放出をある程度補償できる可能 性を示しており，これらを組み合わせて，カオトロピック エッチングにより形成可能な最小ウェルの製作条件を確立 することが今後の課題となる。想定するウェルサイズがア ガロース層の膜厚に比べて十分大きい場合には, 加工は深 さ方向基板表面まで達すると考えられるが，さらに小さな サイズを想定する場合には, 深さ方向の加工形状について 注意する必要がある。

直径 $100 \mu \mathrm{m}$ 以下のウェル作成条件の確立を前提に, ウェ ル間を結ぶマイクロチャネルの製作が次のステップとな る。マイクロチャネルは線状の構造を持ち, ウェル内に格 納された神経細胞から伸張する神経突起が通る通路の役割 を果たす。既に確立されている photo-thermal 法(10)(11) と同様
に，予め作成しておいた，細胞を格納するためのウェル同 土を, より小さなウェルを線状に連続的に配置したチャネ ルによってつなげるという手順でマイクロパターンを得る

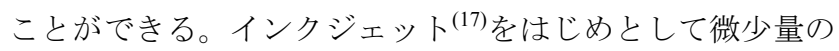
液滴を操作する技術は多様な手法が研究されており ${ }^{(18)}$, こ れらの技術に基づく放出液量と走查速度制御の組み合わせ により, チャネル形成が容易になり，作成可能なウェルサ イズの縮小と共にマイクロパターン全体の微細化が期待さ れる。

〈4·2〉 マルチウェル構造による細胞培養アガロー ス膜に対するカオトロピックエッチングにより形成したマ イクロウェル内で神経細胞の培養が可能であることを確認 した。化学的な処理の影響として, (1)基板上にコーティン グした細胞接着性因子（ポリリジン）の変性，(2)アガロー ス層内の残留試薬による細胞毒性の 2 つが想定されたが, ウェル底面への細胞接着, その後の細胞成長について, 通 常の細胞培養条件下の試料との差異は認められなかったこ とから, 本研究で提案する加工プロセスは細胞培養に対し て問題なく利用できると言える。

今回検討したカオトロピックエッチング条件下で, 直径 100-600 $\mu \mathrm{m}$ のウェルを多電極付細胞培養基板に多数配置す ることができた。このような, 単一細胞を対象とする条件 に比べて大きなサイズのマルチウェル構造を, 複数の細胞 群共培養系に適用することが考えられる。1990 年の時点で, 既にマルチコンパートメントの培養血を利用した神経細胞 の培養刺激実験系の構築が報告されている ${ }^{(19)}$ 。この報告は 2 つのコンパートメントに分離して培養した細胞群に対して 電気刺激を印加し, 共通のターゲットに向かって突起を伸 ばす様子を指標に活動依存性の変化を比較したものであ る。カオトロピックエッチングにより得られるマルチウェ ル構造は, このような “複数の細胞群”を対象とする実験 に適用可能な基板を作成する簡便な手法としても有効であ ると考えられる。

\section{5. 結 論}

培養細胞のパターニンングに有効な基板表面材料である アガロースについて, マイクロウェル構造を形成する手法 を開発した。NaI の有するカオトロピック効果を利用するこ とにより, アガロース薄膜の化学的なエッチングが可能で あることを示した。乾燥状態のアガロース薄膜表面に NaI 水溶液を充填したガラスマイクロピペットを接触させるこ とにより, 溶液の放出が起こる。エッチングされる範囲は 放出される溶液量とアガロース層内の拡散距離によって決 まり, 前者はピペット先端の開口径と印加圧力, 接触時間, 後者はカオトロピック効果で変性したアガロース層を溶解 除去するまでの時間で制御できる。先端径 $10 \mu \mathrm{m}$ のピペッ 卜を用いて圧力 0 , 接触時間 $1 \mathrm{~s}$, 拡散時間 $60 \mathrm{~s}$ という条件 で, 直径約 $100 \mu \mathrm{m}$ のウェルが得られることを確認した。サ イズ 100-600 $\mu \mathrm{m}$ の範囲でサイズを制御したウェルを得る条 件を確立し，また，多数のウェルをマトリクス上に配置し 
た培養基板の作成，MEA 基板上のウェル形成も可能である ことを示した。加工プロセスで使用するマイクロピペット とマイクロマニピュレータは通常の電気生理実験に使用す る標準的な装置がそのまま利用できることから，幅広い応 用が可能である。本手法によって形成したウェル内でラッ 卜海馬神経細胞の培養を試み, 単一細胞についても, 細胞 群についても基板への細胞接着, 突起の成長が良好である ことを確認した。MEA 基板上にカオトロピックエッチング を適用して作成されたウェル内で培養された神経細胞の電 気活動計測を行うことがこれからの課題として挙げられ る。

より小さな先端径のピペットを使用し，時間的な制御パ ラメータと組み合わせて $100 \mu \mathrm{m}$ 以下のマイクロウェルを再 現性良く形成する条件を確立することが今後の課題であ る。これにより, 線状にウェルを連続的に配置することで ウェル間を結ぶチャネル構造の加工が可能になる。さらに, インクジェット方式等で利用されている微量液滴放出制御 技術の利用により，細胞接着領域の微細化と自在な設計が 可能になると考えられる。本手法によって形成したマルチ ウェル細胞培養基板を利用し, 単一細胞とそのネットワー クとしての活動の同時計測, 異なる部位から採取した細胞 や細胞群の共培養系における振る舞いの観測などを目標 に, 今後研究を進める。

(平成 19 年 5 月 17 日受付, 平成 19 年 7 月 9 日再受付)

\section{文献}

(1) G. Stuart and B. Sakmann : "Active propagation of somatic action-potentials into neocortical pyramidal cell dendrites", Nature, Vol.367, pp.69-72 (1994)

(2) R. Malenka and M. Bear : "LTP and LTD: An embarrassment of riches", Neuron, Vol.44, pp.5-21 (2004)

(3) G. Banker and K. Goslin : Culturing Nerve Cells, The MIT Press (1998)

(4) P. Letourneau : "Cell-to-substratum adhesion and guidance of axonal elongation”, Dev. Biol.,Vol.44, pp.92-101 (1975)

(5) P. Clark, P. Connolly, A. Curtis, J. Dow, and C. Wilkinson : "Topographical control of cell behavior .2. multiple grooved substrata", Dev., Vol.108, pp.635-644 (1990)

(6) D. Kleinfeld, K. Kahler, and P. Hockberger : "Controlled outgrowth of dissociated neurons on patterned substrates", J. Neurosci., Vol.8, pp.4098-4120 (1988)

(7) J. Pine : "Recording action-potential from cultured neurons with extracellular micro-circuit electrodes", J. Neurosci Methods, Vol.2, No.1, pp.19-31 (1980)

(8) G. W. Gross : "Simultaneous single unit recording invitro with a photoetched laser deinsulated gold multi-micro-electrode surface", IEEE Trans Biomed Eng., Vol.26, No.5, pp.273-279 (1979)

(9) J. Chang, G. Brewer, and B. Wheeler : "Neuronal network structuring induces greater neuronal activity through enhanced astroglial development", J. Neural Engng., Vol.3, pp.217-226 (2006)

(10) H. Moriguchi, K. Takahashi, Y. Sugio, Y. Wakamoto, I. Inoue, Y. Jimbo, and K. Yasuda : "On-chip neural cell cultivation using agarose-microchamber array constructed by a photothermal etching method", Electrical Engineering in Japan, Vol.146, No.2, pp.37-42 (2004)

(11) K. Kojima, H. Moriguchi, A. Hattori, T. Kaneko, and K. Yasuda : "Two-dimensional network formation of cardiac myocytes in agar microculture chip with $1480 \mathrm{~nm}$ infrared laser photo-thermal etching", Lab Chip., Vol.3, No.4, pp.292-296 (2003)

(12) I. Suzuki, Y. Sugio, Y. Jimbo, and K. Yasuda : "Stepwise pattern modification of neuronal network in photo-thermally-etched agarose

architecture on multi-electrode array chip for individual-cell-based electrophysiological measurement”, Lab Chip., Vol.5, pp.241-247 (2005)

(13) A. Tanaka, S. Ban, S. Imamura, and K. Onose : "Resolution characteristics of novel silicone-based positive photoresist", J. Vac. Sci. Technol., Vol.B7, pp.572-575 (1989)

(14) Y. Jimbo, N. Kasai, K. Torimitsu, T. Tateno, and H. Robinson : "A system for MEA-based multi-site stimulation", IEEE Trans. BME, Vol.50, pp.241-248 (2003)

(15) S. Moelbert and P. De Los Rios : "Chaotropic effect and preferential binding in a hydrophobic interaction model", J. Chem. Phys., Vol.119, pp.7988-8001 (2003)

(16) G. Banker and K. Goslin : Culturing Nerve Cells, $2^{\text {nd }}$ edition, The MIT Press (2002)

(17) N. E. Sanjana and S. B. Fuller : "A fast flexible ink-jet printing method for patterning dissociated neurons in culture", J. Neurosci Methods, Vol.136, pp.151-163 (2004)

(18) T. Nisisako, T. Torii, T. Takahashi, and Y. Takizawa : "Synthesis of monodisperse bicolored janus particles with electrical anisotropy using a microfluidic co-flow system", Adv. Mat., Vol.18, pp.1152-1156 (2006)

(19) P. Nelson, D. Fields, C. Yu, and E, Neale : "Mechanisms involved in activity-dependent synapse formation in mammalian central nervous system cell cultures", J. Neurobiol., Vol.21, pp.138-156 (1990)

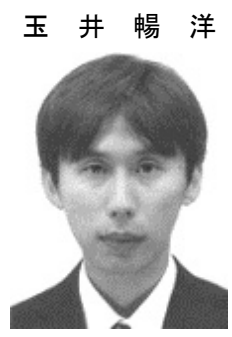

（非会員） 1983 年 3 月 16 日生。 2006 年 3 月東 京大学工学部システム創成学科卒業。同年東京 大学大学院工学系研究科精密機械工学専攻入 学, 現在に至る。神経細胞パターニング技術の 開発とそれを利用したパターン化培養神経ネ ットワークの活動計測を行っている。

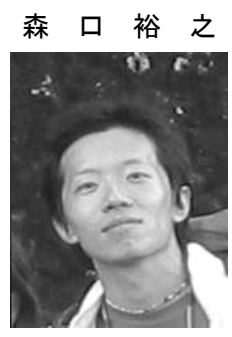

（非会員） 1977 年 8 月 8 日生。 2006 年 3 月東 京大学大学院総合文化研究科修了, 学術博士。 2006 年 4 月日本学術振興会特別研究員。多細胞 組織の構築と機能の仕組みについて理解を進 めて行きたいという考えで技術開発と生理学 実験を行っている。日本生物物理学会会員。

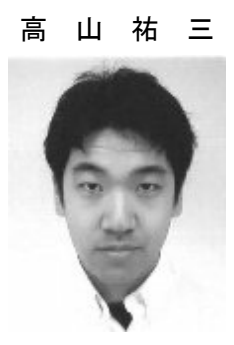

(非会員) 2005 年東京大学工学部システム創成 学科卒業。現在東京大学大学院新領域創成科学 研究科人間環境学専攻博士課程在学中。微細加 工技術, 光学測定をはじめとする工学技術を用 い, 脳神経系の構築・機能制御の機構を明らか にする研究に従事している。

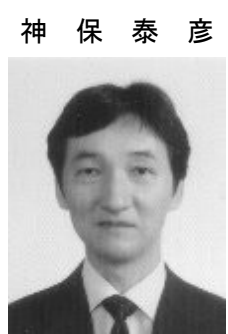

員。
(正員) 1988 年東京大学大学院（電子工学) 修了, 工学博士。同年, NTT 基礎研究所研究員。 1992-1993 年, フランス CNRS 客員研究員。2003 年, 東京大学大学院工学系研究科精密機械工学 専攻助教授, 2006 年より同新領域創成科学研究 科人間環境学専攻教授。主として, 神経工学の 研究に従事。電気学会, 電子情報通信学会, 神 経科学学会, 日本生体医工学会, IEEE 等の会 
鈴 木 郁 郎 (非会員) 2005 年東京大学大学院総合文化研究 科修士課程修了。2005 年より日本学術振興会特 別研究員。現在, 東京大学大学院総合文化研究 科博士課程在学中。日本生物物理学会, 日本神 経学会, Biophysical Society, U.S., Society for Neurocience 会員。
安田賢 二 (非会員) 1992 年早稲田大学大学院理工学研究

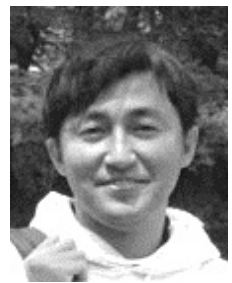
科修了，理学博士。同年より 1999 年まで（株） 日立製作所基礎研究所にてバイオ研究に従事。 1999 年より東京大学大学院総合文化研究科助 教授。2006 年より東京医科歯科大学生体材料工 学研究所教授。また, 2005 年より Stanford 大学 Genome Technology Center 客員教授。日本生物 物理学会, 日本応用物理学会, 日本音響学会,

日本サイトメトリー学会, Biophysical Society, U.S., Acoustical Society of America 会員。 